\title{
SESJA PODSUMOWUJĄCA II ETAP PROJEKTU „PARAFIE I KOŚCIOŁY POLSKIE W USA. POLISH CATHEDRALS” UNIWERSYTET KARDYNAŁA STEFANA WYSZYŃSKIEGO WARSZAWA, 19 GRUDNIA 2018
}

DOI: http://dx.doi.org/10.18290/sp.2019.20

Dnia 19 grudnia 2018 r. na Uniwersytecie Kardynała Stefana Wyszyńskiego w Warszawie odbyła się sesja podsumowująca II etap projektu naukowo-badawczego „Parafie i kościoły polskie w USA. Polish Cathedrals”. Podobnie jak w roku poprzednim, w ramach projektu finansowanego przez Ministerstwo Kultury i Dziedzictwa Narodowego współpracowały ze sobą: Towarzystwo Przyjaciół KUL, Ośrodek Badań nad Polonią i Duszpasterstwem Polonijnym KUL, Instytut Historii Sztuki UKSW i Narodowy Instytut Dziedzictwa Kulturowego za Granicą POLONIKA. Drugi etap badań dotyczył Polish Cathedrals położonych w Cleveland, Buffalo, Detroit, Pittsburgu, wokół tych ośrodków polonijnych oscylowały też referaty zaprezentowane podczas sesji.

Dr hab. Jacek Gołębiowski, prof. KUL, kierownik projektu, w wystąpieniu pt. „Polonia w Detroit i jej formy aktywności” pokrótce scharakteryzował migrację polską do Stanów Zjednoczonych, zwracając uwagę na dzieje polonijnego osadnictwa w głównym mieście stanu Michigan. Nakreślił dziejowy obraz najważniejszych filarów Polonii w Detroit: dzielnic, parafii, szkół, organizacji, których współdziałanie złożyło się na powstanie jednej z największych wspólnot polskich na terenie USA. Świadczyć o tym może przede wszystkim powstanie trzynastu (obecnie istniejących 11) monumentalnych kościołów, zaliczanych do kategorii Polish Cathedrals. Tematyka poruszona w referacie prof. Gołębiowskiego jest ważna dla Ośrodka Badań nad Polonią i Duszpasterstwem Polonijnym KUL również ze względu na fakt, iż podejmowana była już w badaniach ks. prof. Piotra Tarasa SAC, byłego pracownika Ośrodka, czego wynikiem jest obszerna monografia Polonia w Detroit (Warszawa 1989).

Referat dr. Pawła Sieradzkiego (KUL) „Polacy w Buffalo i Cleveland - odrębność i asymilacja" zawierał opis tych przemysłowo-handlowych miast, których charakter sprzyjał osiedlaniu się dużych grup Polaków. Przedstawił również sylwetki twórców i organizatorów tamtejszej Polonii i duszpasterstwa polonijnego, ks. Jana Pitassa i Franciszka Kołaszewskiego - pierwszy z nich założył najstarszą polską parafię w Buffalo (św. Stanisława Biskupa i Męczennika), natomiast aktywność drugiego przyczyniła

Mgr Maria AnNA FurTAK - doktorantka, Instytut Historii na Wydziale Nauk Humanistycznych Katolickiego Uniwersytetu Lubelskiego Jana Pawła II; e-mail: furtakma@gmail.com 
się do powstania kościoła polskokatolickiego w USA. Ponadto dr Sieradzki wyróżnił przykłady świadczące o utrzymywaniu własnej świadomości narodowej przez Polaków w Buffalo i Cleveland, takie jak zorganizowanie polskich dzielnic (Stanisławowo, Polish Village), powstanie Niagara Camp w czasie I wojny światowej i udział Polaków w Armii Hallera, powstanie polskich mediów, przede wszystkim radiowej audycji Godzina Różańcowa Ojca Justyna w Buffalo. Za symboliczny punkt zwrotny w dziejach Polonii amerykańskiej, przeważający szalę między odrębnością a asymilacją przyją Kongres Eucharystyczny w Chicago w 1926 r., kiedy polscy biskupi po powrocie do kraju, w obawie przed wynarodowieniem pozostających w USA Polaków, podjęli próby utworzenia duszpasterstwa dla tamtejszej Polonii.

Dr hab. Anna Czyż (UKSW) swój referat rozpoczęła od przypomnienia historii polskiej emigracji do Stanów Zjednoczonych - głównych miejsc osadnictwa, osób odpowiedzialnych za organizowanie skupisk polonijnych, takich jak o. Moczygemba czy Wincenty Barzyński, oraz parafii, które stanowiły przestrzeń życia nie tylko religijnego, ale także politycznego i kulturalnego. Następnie autorka omówiła Polish Cathedrals, podała etymologię tej nazwy i krótko scharakteryzowała obiekty zaliczane do tej kategorii. Zwróciła uwagę na dwojaki sposób postrzegania Polish Cathedrals współcześnie, mianowicie można zaobserwować przypadki ich burzenia, ale także poszanowania, czego wyrazem było uhonorowanie kościoła Saint John Cantius w Chicago w konkursie „Church Madness 2016”. Według autorki odrębność Polish Cathedrals zakorzeniona jest w szeroko pojętej polskości, związana zarówno z historią narodową, jak i typową dla Polaków religijnością.

Wystąpienie dr. Bartłomieja Gutowskiego (UKSW) dotyczyło architektury dziewięciu Polish Cathedrals w Detroit. Autor podał krótką charakterystykę architektury i historię kościołów polskich w USA. Wyraził wątpliwość co do istnienia kategorii Polish Cathedrals, zwracając uwagę, że wiele monumentalnych i zasługujących na uznanie polskich kościołów w USA nie zostało włączonych do listy tzw. polskich katedr. Opisał również proces formowania się Polish Cathedrals, ich charakterystyczny aspekt architektoniczny, czyli historyzm i monumentalizm, a także podkreślił „długie trwanie" stylu tych szczególnych polskich kościołów, który od lat 50. XX wieku został zastąpiony przez modernizm.

Dr Gutowski dokonał zwięzłego opisu architektury poszczególnych Polish Cathedrals w Detroit, wymieniając podstawowe informacje, takie jak: nazwisko architekta, rok powstania, styl architektoniczny, wskazując przy tym na nawiązania do innych budowli, związki z architekturą europejską, w tym polską, co uwydatniło się zwłaszcza w polskich motywach dekoracyjnych. Szczególne miejsce poświęcił Ralphowi Adamsowi Cramowi, budowniczemu kościoła św. Floriana w Hamtramck, który jest przykładem czystego stylu neogotyckiego. Prelegent wspomniał również o reminiscencjach polskości i swojskości w architekturze polskich kościołów w USA, przez co możliwe jest uchwycenie licznych nawiązań do monumentalizmu kościołów w Polsce. 
Dr hab. Katarzyna Chrudzimska-Uhera, prof. UKSW, w wystąpieniu „Znaki ojczyzny i tradycji w Polish Cathedrals" omówiła rolę elementów polskości w tych budowlach, kierując się teorią B. Andersona o „wspólnocie wyobrażonej”, według której naród jest wyobrażony przez siebie samego. Znaczy to, że Polacy w diasporze amerykańskiej sami wytworzyli swoją wspólnotę, czyli Polonię, opierając się na motywach i tradycjach zaczerpniętych z Ojczyzny. Autorka wymieniła charakterystyczne cechy w wystroju Polish Cathedrals, przede wszystkim kult maryjny w postaci obrazów i rzeźb przedstawiający Matkę Boską, a obecnie także Jana Pawła II jako przewodników współczesnej Polonii. Oprócz tego, silnym akcentem nawiązań do tradycji przodków są inspiracje sztuką polską, przytaczając wiele przykładów (m.in. kopie dzieł Piotra Stachiewicza, Zofii Stryjeńskiej, Wojciecha Kossaka, fortepian Paderewskiego, relikwie wtórne obrazu jasnogórskiego). Te liczne symbole polskiej kultury i narodowości nieodmiennie występujące w Polish Cathedrals, pełnią rolę łączącą Polonię z tradycją i kulturą Ojczyzny, nadając jej niepowtarzalny charakter.

Sesja podsumowująca II etap projektu uwidoczniła, jak wiele aspektów związanych z historią i działalnością Polonii w Stanach Zjednoczonych jest wartych naukowej uwagi i przeprowadzenia nad nimi pogłębionych badań. Kontynuowane będą one w roku 2019 i obejmą Polish Cathedrals m.in. w Milwaukee, Philadelphii i Baltimore. Etap III będzie zwieńczeniem prowadzonego od 2016 r. projektu, który zakłada kwerendę źródłową i dokumentację fotograficzną 56 świątyń zaliczanych do kategorii Polish Cathedrals. 